\title{
Life Cycle Energy Analysis (LCEA) of Cooking Fuel Sources Used in India Households
}

\author{
Punam Singh", Haripriya Gundimeda \\ Department of Humanities \& Social Sciences, Indian Institute of Technology-Bombay, India \\ ${ }^{*}$ Corresponding Author: punam29@gmail.com
}

Copyright $@ 2014$ Horizon Research Publishing All rights reserved.

\begin{abstract}
The purpose of this paper is to analyze various cooking fuel options commonly used in Indian households, namely, liquefied petroleum gas (LPG CO) derived from crude oil and (LPG NG) natural gas, kerosene, coal, electricity, firewood, charcoal, crop residues, dung cake and biogas. In this paper, we used life cycle energy analysis approach to determine the life cycle energy efficiency (LCEE) of cooking fuels. The daily heat energy requirement by the Indian households for cooking activities is about 2150 kcal. Amongst the analyzed fossil fuels, LPG derived from natural gas has the highest energy efficiency of $45 \%$ and coal with $14.7 \%$ is the least energy efficient fossil fuel option for household cooking. The life cycle energy efficiency of traditional biomass fuels is $11.9-7.5 \%$, which is much lower than those of commercial cooking fuels like LPG and kerosene. The life cycle energy efficiency of charcoal is found to be $9 \%$ and is lower than that of firewood. The energy efficiency of biogas is found to be comparable to that of LPG and is potentially a sustainable cooking fuel option in Indian context.
\end{abstract}

Keywords Life Cycle Energy Efficiency, Cumulative Energy Demand, Cooking Energy Demand, Traditional Fuels, Fossil Fuels

\section{Introduction}

Cooking activities can be traced back to the early years of social evolutionary stages of human civilization and continues to be the most fundamental necessity of human society. The pattern of household cooking energy consumption is representative of country's socio-economic well being. In other words, the accessibility and affordability of cooking fuel options to the households can be said to be a key determinant of economic development and inclusive growth. In India, the most significant aspect of residential cooking energy consumption is the extent of disparity in the energy use between rural and urban areas of the country. While a majority of the rural households depend on traditional cooking fuels such as firewood $(62.5 \%)$, crop waste $(12.3 \%)$ and dung cake (10.9\%), a large number of households in urban areas depend on LPG (65\%), kerosene $(7.5 \%)$ and coal $(2.9 \%)$ for cooking purposes [1]. The cooking fuel consumption trend in urban areas of past few decades' show that firewood and coal were the principle energy carriers for cooking until mid 1970's but gradually kerosene substituted the coal and post liberalization, the consumption of liquefied petroleum gas (LPG) has been steadily rising. The kerosene use has been on a constant decline since 1999 and the rate of decline is almost equal to the rate of increase in the LPG consumption. The consumption of firewood, which is largely used by the low income households has remained almost constant since 1991. The consumption of coal has been mostly limited to areas around coal mines and has remained fairly constant at about $3 \%$. In rural areas, firewood and dung cake were the main energy carriers for cooking activities during mid 70's and continues to be the dominant cooking fuel resource till date. Although the accessibility of LPG has been increasing in rural areas since 1999, but the fuel transition observed is largely from kerosene to LPG. Both LPG and kerosene for the residential sector is disseminated through an aggressive subsidization policy of the Indian government.

The fuel type and consumption pattern are also influenced by income levels of the households and various studies have shown the positive relationship between the increase in income to the fuel transition up the energy ladder, i.e. from biomass to kerosene to LPG and/or electricity, in terms of quality, user convenience and cost [2]. The 'energy ladder hypothesis' is somewhat skewed, particularly in rural areas where high income households tend to use biomass fuels too along with commercial fuels because of its local availability and taste preferences of certain dishes like unleavened bread, rice dishes cooked in earthen pots etc [3]. Rural households collect fuel from various sources such as animals, forestland or open land surrounding their villages and a considerable amount of time and manual labour is spent in gathering, collection, making, drying, stocking etc of biomass fuels [4-5]. The direct consequences for the poor are that precious time is lost in collecting low quality and low efficient fuels, thereby reducing their ability to accumulate the financial resources they need to invest in strategies for improving their 
livelihoods $[2,6]$. Most energy analysis studies do not account for the manual labour associated with the use of biofuels. Numerous studies have shown that the resulting indoor air pollution from the dominant use of solid biofuels has serious repercussions on the health of the household dwellers [7-10] besides causing local and global environmental impacts due to atmospheric deposition of carbonaceous aerosols [11-14]. On the other hand, substituting the traditional fuels with cleaner fossil fuels may be useful in countering the adverse health impacts but may lead to long term global environmental impacts, such as climate change, terrestrial acidification, eco-toxicity etc [15-19]. Moreover, they are essentially non-renewable finite resources and studies have shown that they are depleting at an alarming rate. For example, Lior [20] assumed constant fossil fuel production rates and then estimated the ratio of production to reserves to be approximately 40,60 and 150 years for oil, gas and coal, respectively. Earlier studies on cooking fuel use have mostly focused on the energy efficiency and emissions from combustion stoves [15, 21], fuel production plants [22], economic analysis $[2,3,6]$ etc.

This paper aims to analyze quantitatively energy consumption of households using 'life cycle energy analysis' (LCEA) approach. Life cycle methodologies have become increasingly popular amongst researchers, product manufacturers, environmental scientists, toxicologists, project developers and more recently with policy makers due to its holistic and scientific approach to system analysis to assess the energetic and environmental performance of product systems from 'cradle-to-grave' [23-27]. The overall objective of this paper is to determine: (a) the average daily cooking heat energy requirement of Indian households; (b) energy equivalent of manual labour involved in collecting and preparing biomass cooking fuels; and (c) the life cycle energy efficiency (LCEE) of various cooking fuel options, namely, LPG (CO), LPG (NG), kerosene, coal, electricity, firewood, crop residues, dung cake, charcoal and biogas. LPG derived from crude oil (LPG-CO) and natural gas (LPG-NG) are treated separately because they follow altogether different production routes.

\section{Methodology}

Pursuant to the main objective the methodologies adopted for this study is discussed in the following sections:

\subsection{Estimation of Average Daily Heat Energy Required by Households}

The actual energy requirement for cooking depends on several factors namely, fuel used, stove efficiency, dish ingredients, cooking methods etc. In India, households use various fuel mixes from traditional biomass fuels combusted in stoves locally made from mud, bricks or clay to fossil fuels combusted in various types of commercial stoves. Moreover, the dishes cooked also varies to a large extent influenced by income levels, regional tastes and flavor and several cooking methods from boiling to the hot plate open baking. This non-uniformity makes the task of determining average cooking energy demand for an average household extremely complex. Several studies have employed various methods to estimate cooking energy demand in India e.g. [3, 21, 28].

Table 1. Cook stoves and measuring instruments used for experiment

\begin{tabular}{|c|c|c|}
\hline Description & Technical specifications & Remark \\
\hline LPG stove & $\begin{array}{l}\text { 'Supreme' make stainless steel } 4 \text { burner stove and } \\
5 \mathrm{~kg} \text { mini cylinder }\end{array}$ & medium sized burner used \\
\hline Pressure kerosene stove & $\begin{array}{l}\text { 'Premier' make with } 3 \text { liter tank modified to fit } \\
\text { pressure gauge and release valve }\end{array}$ & local modification \\
\hline Electric heater & $1.3 \mathrm{~kW}$ local made helical coil heater & $0.9 \mathrm{~kW}$ measured \\
\hline Digital multimeter & $\begin{array}{l}\text { 'Fluke' make industrial multimeter with Range: } \\
0-10 \mathrm{~A}, \text { Accuracy } \pm 0.5 \%\end{array}$ & $\begin{array}{l}\text { for measuring voltage and current } \\
\text { of heater }\end{array}$ \\
\hline Weighing scale (big) & $\begin{array}{l}\text { 'Maxsell' make bench scale with Range: } 0-15 \mathrm{~kg} \text {, } \\
\text { Accuracy } \pm 0.5 \mathrm{~g}\end{array}$ & $\begin{array}{l}5 \mathrm{~kg} \mathrm{LPG} \text { cylinder was placed on } \\
\text { this scale }\end{array}$ \\
\hline Weighing scale (small) & $\begin{array}{l}\text { 'Maxsell' make precision scale with Range: } 0-6 \\
\qquad \mathrm{~kg}, \text { Accuracy } \pm 0.1 \mathrm{~g}\end{array}$ & $\begin{array}{l}\text { for measuring fuel, ingredients } \\
\text { etc. }\end{array}$ \\
\hline Precision stop watch & ' $P C F$ ' make, Mode: 00.00 & for timing \\
\hline Digital thermometer & $\begin{array}{c}\text { ' } P C I^{\prime} \text { make, thermocouple probe, }-50^{\circ} \mathrm{C} \text { to } 150^{\circ} \mathrm{C} \text {, } \\
\text { Accuracy } \pm 0.2^{\circ} \mathrm{C}\end{array}$ & for water boiling test (WBT) \\
\hline Cooking vessels & Alloy and steel, different sizes & for WBT and food preparations \\
\hline Beaker & $1000 \& 500 \mathrm{ml}, \mathrm{LC}: 10 \mathrm{ml}$ & for measuring liquid volume \\
\hline Pressure gauge & 'Omega' make, Range: 0-100 psi, Accuracy $\pm 2 \%$ & fitted to the kerosene stove \\
\hline
\end{tabular}


For this study, a simplified experimental setup involving preparation of typical dishes based on average daily food intake reported in National sample survey [29] has been used. Based on the literature survey and discussions with various stakeholders the following assumptions are made: (a) the average net cooking energy demand in rural and urban scenario remains the same if the food type, quantity and cooking methods remain the same; (b) the consumption pattern of cooked food remains largely uniform in rural and urban scenario; (c) the fuel quantity required is determined solely by net calorific value of the fuel used and stove efficiency; and (d) impacts of variable combustion rates during different phases of fuel burning, secondary and/or incomplete combustion etc are assumed to be insignificant. The experiment was performed in a simulated household surrounding using LPG, kerosene and electric cook stoves and measuring instruments (refer Table 1 for details).

The cooking devices are selected for its higher efficiency and better control mechanism for fuel combustion. The thermal efficiencies and fuel consumption rate of cook stoves were determined using standard water boiling test (WBT) using the following simple equations [30].

$$
\begin{gathered}
\text { Stove efficiency }=\varphi_{\text {stove }}=\frac{c p_{w} \times w_{i}\left(T_{f}-T_{i}\right)+\left(2260 \times w_{v}\right)}{F_{d} \times L H V} \\
\text { Stove fuel flow rate }=\boldsymbol{\beta}_{\text {flow }}=\frac{F_{d}}{\left(t_{d} \div 60\right)} \times 1000
\end{gathered}
$$

Where,

$w_{i} \quad=$ initial weight of water in $\mathrm{kg}$

$T_{i} \quad$ initial temperature of water in $\mathrm{oC}$

$T_{f} \quad=$ final temperature of water in $\mathrm{oC}$

$w_{v} \quad=$ water vaporized in $\mathrm{kg}$

$F_{d} \quad=$ fuel consumed in $\mathrm{kg}$

$L H V=$ lower heating value of fuel in $\mathrm{kJ} / \mathrm{kg}$ (for $\mathrm{LPG}$ 45240 \& kerosene $42860 \mathrm{~kJ} / \mathrm{kg}$ )

$c p_{w}=$ specific heat of water in $\mathrm{kJ} / \mathrm{kgoC}$

$$
(=4.186 \mathrm{~kJ} / \mathrm{kgoC})
$$

$t_{d}=$ duration in minutes

Finally, the cook stoves were used to prepare a number of dishes based on the average daily intake of food type and quantity reported by [29] as given in Table 2(a). Two menus (A \& B) were prepared in consultation with women group familiar with rural and urban eating habits and cooking methods by keeping the same quantity of food ingredients but adopting different cooking methods and is presented in Table 2(b). The cooking time of dishes was recorded.

For LPG stove, the steel cylinder was filled with $5 \mathrm{~kg} \mathrm{LPG}$ and the cylinder was placed on the bench scale and weight $\left(W_{i}\right)$ were recorded. A stainless steel pot was filled with $3 \mathrm{~kg}$ of tap water at room temperature (reading taken with digital thermometer, $\left.T_{i}\right)$ and was weighed $\left(w_{i}\right)$ on the precision scale. The pot was placed on medium burner of the stove and the probe (length: $35 \mathrm{~mm}$ ) of the thermometer was fully immersed in the water. The flow control knob of the stove was fixed on the 'medium' and water was allowed to boil without covering. The gas was switched off when the water temperature stabilized at $100{ }^{\circ} \mathrm{C}\left(T_{f}\right)$ and the total duration $\left(t_{d}\right)$ was timed using the stop watch. The pot was weighed $\left(w_{f}\right)$ again on the precision scale. The cylinder weight $\left(W_{f}\right)$ was recorded again. The vapour loss $\left(w_{v}=w_{i}-w_{f}\right)$ and fuel consumption $\left(F_{d}=W_{i}-W_{f}\right)$ was also recorded.

Table 2(a). Estimation of daily food intake by households

\begin{tabular}{|c|c|}
\hline \multicolumn{2}{|r|}{ Menu A } \\
\hline Dish 1 & Rice $(900 \mathrm{~g}+5 \mathrm{~kg}$ water), boiled, vessel covered \\
\hline Dish 2 & Pulses 'dal' ( $115 \mathrm{~g}+1 \mathrm{~kg}$ water), boiled, vessel covered \\
\hline Dish 3 & Vegetable ( $250 \mathrm{~g}$ vegetables, $50 \mathrm{~g}$ oil), fried, open vessel \\
\hline Dish 4 & $\begin{array}{c}\text { Vegetable (400g vegetables, } 65 \mathrm{~g} \text { oil), fried and boiled, } \\
\text { vessel covered }\end{array}$ \\
\hline Dish 5 & Milk $750 \mathrm{ml}$, boiled, open vessel \\
\hline Dish 6 & Leaf bread 'chapatis' ( $680 \mathrm{~g}$ wheat), hot plate cooking \\
\hline Dish 7 & Tea -5 cups $(15 g+75 g$ sugar), boiled adding $100 \mathrm{ml} \mathrm{milk}$ \\
\hline \multicolumn{2}{|r|}{ Menu B } \\
\hline Dish 1 & $\begin{array}{c}\text { Porridge 'khichdi' (700 g rice }+115 \mathrm{~g} \text { pulses }+5.5 \mathrm{~kg} \text { water), } \\
\text { boiled, vessel covered }\end{array}$ \\
\hline Dish 2 & $\begin{array}{c}\text { Vegetable (650 g vegetables, } 75 \mathrm{~g} \text { oil), fried and boiled, } \\
\text { vessel covered }\end{array}$ \\
\hline Dish 3 & $\begin{array}{l}\text { Porridge 'kheer' (milk } 750 \mathrm{ml}+\text { rice } 200 \mathrm{~g} \text { ), boiled, open } \\
\text { vessel }\end{array}$ \\
\hline Dish 4 & Fried Leaf bread 'parathas' ( $680 \mathrm{~g}$ wheat), hot plate cooking \\
\hline Dish 5 & Tea -4 cups $(15 g+60 g$ sugar $)$, boiled \\
\hline
\end{tabular}

\begin{tabular}{cccc}
\hline $\begin{array}{c}\text { Main } \\
\text { ingredients }\end{array}$ & $\begin{array}{c}\text { Rural (ri) } \\
\text { Per capita per month } \\
\text { consumption }\end{array}$ & $\begin{array}{c}\text { Urban (ui) } \\
\text { aDaily food } \\
\text { consumption/HH }\end{array}$ \\
\hline Rice (g) & 6000 & 4520 & 900 \\
Wheat (g) & 4250 & 4080 & 680 \\
Pulses (g) & 650 & 790 & 115 \\
Edible oil (g) & 640 & 820 & 115 \\
Milk (ml) & 4100 & 5400 & 750 \\
Vegetables $(\mathrm{g})$ & 4080 & 3950 & 650 \\
Tea $(\mathrm{g})$ & 75 & 94 & 15 \\
\hline & \multicolumn{4}{c}{ a Daily average food consumption/ }
\end{tabular}

Table 2(b). Estimation of daily food intake by households

For kerosene stove, $1 \mathrm{~kg}$ kerosene was measured and filled in the kerosene stove tank $\left(W_{i}\right)$. An optimal tank air pressure of 45 psi was generated using the stove pump. The water boiling experiment was conducted similar to that of LPG. The fuel flow rate was maintained by intermittently using the air pump to maintain tank pressure at 45 psi. After completion of the experiment 30 minutes was given for the stove atomizer and the tank to cool down to room temperature and then kerosene was drained from the stove tank and weighed $\left(W_{f}\right)$ on the precision scale to determine the quantity of the fuel use. For electric stove, initial reading of the supply voltage was taken (average 218 volts). The current was allowed to pass through the coil with the 'digital ammeter' in series and the most constant value of current 
(average 4.13 amps) during the entire duration of water boiling was recorded. The experiments were repeated twice on different days with 2 and $1 \mathrm{~kg}$ water in the pot. The results are summarized in Table 3.

The second part of the experiment included cooking the various dishes and recording the cooking time. The fuel consumption of LPG and kerosene was maintained by keeping the control knob and tank pressure at similar levels as in water boiling test. The electric heater always operated on same settings as it did not have any control switch. The results are summarized in Table 4 .

The daily heat energy requirement per household for cooking for LPG, kerosene and electricity can be determined by using the following equation.

Daily heat energy requirement

$$
=\mathrm{LHV}^{*}\left(\operatorname{avg} . \boldsymbol{\varphi}_{\text {stove }}\right) *\left(\operatorname{avg} . \boldsymbol{\beta}_{\text {flow }} / \mathbf{1 0 0 0}\right) *\left(\text { avg. } \mathrm{t}_{\mathrm{c}} / 60\right)
$$

The average heat energy requirement per household for daily cooking activities is estimated at $2150 \mathrm{kcal}$. This estimate broadly compares with 1515 2271 kcal of Planning Commission of India and 2629 kcal estimate of Venkataraman et al.[28] which is based on the consumption of biomass fuels.

Table 3. Results of water boiling test

\begin{tabular}{|c|c|c|c|c|c|c|c|c|}
\hline Cook Stove & $\begin{array}{r}\boldsymbol{w}_{\boldsymbol{i}} \\
(\mathrm{kg})\end{array}$ & $\begin{array}{r}\boldsymbol{T}_{\boldsymbol{i}} \\
(\mathrm{o} \mathrm{C} \\
\end{array}$ & & $\begin{array}{c}\boldsymbol{w}_{v} \\
(\mathrm{~kg})\end{array}$ & $\begin{array}{r}\boldsymbol{F}_{\boldsymbol{d}} \\
(\mathrm{kg})\end{array}$ & $\begin{array}{c}\mathrm{td} \\
(\mathrm{min})\end{array}$ & $\begin{array}{c}\boldsymbol{\beta}_{\text {flow }} \\
(\mathrm{gm} / \mathrm{hr})\end{array}$ & $\varphi_{\text {stove }}(\%)$ \\
\hline \multirow{4}{*}{ LPG } & 3 & 28 & & 0.052 & 0.041 & 17.04 & 144.37 & 55.01 \\
\hline & 2 & 30 & & 0.079 & 0.031 & 12.89 & 144.30 & 54.45 \\
\hline & 1 & 31 & & 0.119 & 0.022 & 9.22 & 143.38 & 56.00 \\
\hline & 3 & 28 & & 0.069 & 0.056 & 26.66 & 126.03 & 44.11 \\
\hline \multirow[t]{3}{*}{ Kerosene } & 2 & 30 & & 0.095 & 0.042 & 20.12 & 125.25 & 44.43 \\
\hline & 1 & 31 & & 0.137 & 0.030 & 14.28 & 126.05 & 46.51 \\
\hline & 3 & 28 & & 0.123 & 0.51 & 33.82 & 0.905 & 64.31 \\
\hline \multirow[t]{2}{*}{ Electric } & 2 & 30 & & 0.147 & 0.39 & 25.94 & 0.902 & 65.34 \\
\hline & 1 & 31 & & 0.171 & 0.28 & 18.67 & 0.899 & 66.95 \\
\hline \multirow{3}{*}{ Particul-ars } & \multicolumn{3}{|c|}{ LPG stove } & & \multicolumn{2}{|c|}{ Kerosene stove } & \multicolumn{2}{|c|}{ Electric stove } \\
\hline & Menu A & & Menu B & & Menu A & Menu B & Menu A & Menu B \\
\hline & \multicolumn{8}{|c|}{ Cooking time in minutes per prepared dish } \\
\hline Dish 1 & 31.17 & & 38.19 & & 40.78 & 46.19 & 49.96 & 52.14 \\
\hline Dish 2 & 33.49 & & 37.58 & & 47.67 & 49.91 & 52.78 & 58.25 \\
\hline Dish 3 & 21.49 & & 33.32 & & 33.15 & 47.82 & 47.11 & 61.84 \\
\hline Dish 4 & 31.28 & & 34.83 & & 46.28 & 51.47 & 52.94 & 56.39 \\
\hline Dish 5 & 14.12 & & 5.91 & & 21.31 & 7.98 & 26.67 & 10.82 \\
\hline Dish 6 & 21.72 & & $\mathrm{x}$ & & 24.19 & $\mathrm{x}$ & 32.81 & $\mathrm{x}$ \\
\hline Dish 7 & 7.28 & & $\mathrm{x}$ & & 9.38 & $\mathrm{x}$ & 12.16 & $\mathrm{x}$ \\
\hline Time (Total) & 160.55 & & 149.83 & & 222.76 & 203.37 & 274.43 & 239.44 \\
\hline Time (avg.) & \multicolumn{4}{|c|}{155} & \multicolumn{2}{|c|}{213} & \multicolumn{2}{|c|}{257} \\
\hline
\end{tabular}




\subsection{Estimation of Energy Use Equivalent of Manual Labor}

Manual labor input is rarely accounted in conventional energy analysis studies because it does not contribute directly to any environmental impacts associated with fuel use. For fossil fuels, excluding labor inputs can easily be rationalized because from extraction to transportation, all stages are highly mechanized with extremely high throughputs and man-machine interface are usually limited to operator level. However, for biomass fuels, in particular for developing countries like India, the throughputs are very small (barely sufficing the daily, weekly or monthly requirements of a household) and manual labor required in gathering and processing of biofuels are significant. Therefore, accounting manual labor for energy analysis of biofuels would be desirable, if not compulsory as suggested by standard literature.

The most robust method for estimating the energy equivalence of manual labour would be to convert the energy content of the food intake of workers over and above the minimum calorie intake. However, his approach is not suitable for developing countries, where a large section of the population live below the poverty line (i.e. food intake is below the prescribed minimum calorie intake) and these households are fully dependent on biofuels for cooking energy. The approach taken in this study is based on the method proposed by Zhang and Dornfeld [31], where energy use per worker-hour (EPWH) is derived from non-industrial energy supply, which includes all primary energy except that supplied to industry and transport sectors as given by

$$
\boldsymbol{E P W H}=\frac{\boldsymbol{T P E S}\left(1-\frac{I F C}{T F C}\right)}{\text { population } \times \text { hours per year }}=900 \mathrm{kcal}
$$

Where,

TPES is India's total primary energy supply [32] = 675830 ktoe, and

IFC is industrial and transport final consumption [32] = 187520 ktoe, and

TFC is total final consumption of energy [32] = 449270 ktoe, and

Worker population [33] $=473$ million

\subsection{Life Cycle Energy Efficiency (LCEE)}

The framework for life cycle energy analysis (LCEA) is based on the standardized LCA methodology (ISO 14040 14043) limited to the assessment of energy aspects. LCA gives an objective and holistic basis for comparing energy and material flow through a system, treating the product process chain as a sequence of sub-systems that exchange inputs and outputs [34-35]. Within energy analysis and LCA literature there is lack of consensuses concerning the definition or conventions for energy efficiency calculation methods, particularly for renewable energy systems. Einstein's relativistic considerations makes the full energy content strictly proportional to its mass, the proportionality constant being the square of the velocity of light [23] but is practically impossible to incorporate in LCEA, owing to the technological barrier associated with mass-energy conversions. Moreover, it is not clear if higher or lower heating values of primary energy carriers are to be used in the determination of energy efficiency, the choice is left to the independent judgment of energy analyst.

Broadly the energy efficiency concepts can be classified as (a) climate change oriented approach, where energy inputs derived from fossil resources are accounted; (b) resource conservation approach, where energy inputs derived from non renewable resources (i.e. fossil, nuclear and non-renewable biomass) are accounted; and (c) total energy demand, where all energy resources are accounted [36]. The methodology adopted for this study to compute the energy efficiency of various cooking fuels is based on 'total energy demand' approach. All energy efficiency values originating from this study refer to lower heating value referred as 'net calorific value (NCV)'. Energy equivalent of manual labor inputs has been accounted for all five biofuels i.e. firewood, charcoal, crop residues, dung cake and biogas. The following equations are used to estimate the life cycle energy efficiency of analyzed cooking fuels:

$$
L C E E=\frac{F E C}{E_{p}+E_{t}}
$$

For fossil fuels; $\boldsymbol{E}_{\boldsymbol{t}}=\boldsymbol{E}_{\boldsymbol{d}}+\boldsymbol{E}_{\boldsymbol{m}}+\boldsymbol{E}_{f}+\boldsymbol{E}_{\boldsymbol{e}}$

For biomass fuels; $\boldsymbol{E}_{\boldsymbol{t}}=\boldsymbol{E}_{\boldsymbol{h}}$

\section{Life Cycle Modeling and Energy Analysis}

\subsection{Goal, Scope and Functional Unit}

The goal is to determine the life cycle energy efficiency of heat energy conversion and transfer to the cooking pot from various fossil and biomass resources for household cooking activities. For fossil based cooking fuels, extraction or mining of raw feedstock materials such as crude oil, natural gas and coal, processing of feedstock in refineries or fractioning plants, transportation and combustion of fuels in cook stoves are included in the scope of this study. For biomass fuels, collection, processing (sun drying, making dung cakes etc) and final combustion in cook stoves have been included. Waste treatment or disposal of refinery waste, overburden from coal mines and ash left over in cook stoves from the combustion of solid fuels have been excluded from the scope of energy analysis as their embodied energy content is assumed to be zero. The functional unit for this study is defined as ' $2150 \mathrm{kcal}$ of useful heat energy transferred to cooking pot', which is the daily average requirement of households to prepare basic cooked meals (refer Section 2.1 for details).

\subsection{System Boundary and Life Cycle Inventory}


The system boundary of an LCEA defines the inputs and outputs which are considered in the scope of this study and are described briefly for all the cooking fuels.

Biomass fuels:

In this study manually collected firewood from local areas are considered, which is the usual practice in India. To compute the manual work involved for other biomass fuels, we used estimates of manual labour involved in collecting firewood as estimated by Laxmi et al. [4] as 50 man-hours per household per month as a benchmark in this study. The net calorific value of firewood is $3334 \mathrm{kcal} / \mathrm{kg}$ and the physical losses during collection and transportation of firewood is $4 \%$. The manual labour involved in the physical process of crop residues is taken as 27 man-hour/ month as they are collected from nearby farmlands and are generally collected and stored in bulk towards the end of harvesting season [37]. The collection losses are estimated as $6 \%$, slightly higher than firewood because of smaller pieces. The net calorific value for crop residues is $3069 \mathrm{kcal} / \mathrm{kg}$. The dung of stall fed cattle and buffaloes are converted in dung cakes by mixing it with small quantity of residual feed (mainly straw, wood chips etc) and dung cake of circular shape (weighing 0.5 to $2.5 \mathrm{~kg}$ ) is prepared by hand and put out in the sun for drying. The manual labour and physical losses for dung cake are taken as 35 man-hour/ month and $8.5 \%$, respectively [38-39]. The calorific content of dried dung cake is $2844 \mathrm{kcal} / \mathrm{kg}$ and of fresh manure is taken as $1001 \mathrm{kcal} / \mathrm{kg}$. The cook stove considered for all three traditional biofuels is a ' $U$ ' shaped mud stove made by households using local material and their heat transfer efficiencies are taken as $13.5 \%$ for firewood, $11 \%$ for crop residues and $8.5 \%$ for dung cake [15]. Some of the collected wood is also used in charcoal production which largely operates as informal sector in India. Charcoal is produced by heating wood (or any other raw biomass) in some type of kiln with limited access to air through a process called 'carbonization' (or 'pyrolysis'). Charcoal making kilns can vary greatly in structure, size, efficiency etc. Traditional earth mound, which is the most commonly used kiln type in India, have been considered with $30 \%$ yield and $6551 \mathrm{kcal} /$ $\mathrm{kg}$ calorific content of the produced charcoal. The physical losses are taken as $5 \%$ and the cook stove is a typical metal 'angethi' made locally with $17.5 \%$ stove efficiency [40-41]. The manual labour required for charcoal production is taken as 62 man-hour/ month. Biogas is naturally generated from 'methanogens' i.e. methane producing bacteria in the process of bio-degradation of organic material under anaerobic conditions. Various factors such as design of anaerobic digester, biogas potential of feedstock, type of substrate, $\mathrm{pH}$, temperature, loading rate, hydraulic retention time etc. influence the biogas production. A $2 \mathrm{~m}^{3}$ household type fixed dome anaerobic digester operating in continuous feeding mode is considered in this study. The substrate used is dried manure with $3705 \mathrm{kcal} / \mathrm{kg}$ calorific value mixed with water (1:10 ratio) and the calorific content of the biogas is taken as $4350 \mathrm{kcal} / \mathrm{kg}$. The cook stove considered is a typical biogas stove constructed from mild steel with 55\% heat transfer efficiency $[15,42]$. The manual work involved in operating of the biogas plant is 10 man-hour/ month and the physical losses are taken as $2 \%$. The digested slurry is a useful co-product and can be used to substitute fertilizers to some extent in farming. As the energy content of the digested slurry is considered to be zero it has not been included in this energy analysis. The life cycle energy inventory for biomass and fossil fuels are presented in Table5.

Fossil fuels:

The system boundary for coal mining is modeled for an open cast mine. The main material and fuel used are Ammonium Nitrate-Fuel Oil (ANFO) explosives for blasting operations and diesel for coal extraction [43-45]. The calorific content of coal is taken as $2811 \mathrm{kcal} / \mathrm{kg}$. The average transportation distance is taken as $100 \mathrm{~km}$ and transportation losses are taken as $1 \%$. The cook stove considered is a locally made metal 'angethi' (similar to the charcoal stove) with $15.5 \%$ heat transfer efficiency [28]. The Indian electricity production relies mainly on coal and lignite $(>70 \%)$. The system boundary for electricity generation for this study is based on the coal power plant with average consumption of $641 \mathrm{~g}$ of coal per $\mathrm{kWh}$. The average distance of coal is taken as $1000 \mathrm{~km}$ transported by rail using diesel locomotive and the losses incurred during transportation are taken as $2.7 \%$. The transmission losses are taken as $28 \%$ [46]. The cook stove considered is a $1 \mathrm{~kW}$ commercial electric heater with $70 \%$ heat transfer efficiency [28]. The original raw material for the production of kerosene and liquefied petroleum gas (LPG) is crude oil. LPG is also derived from natural gas, which follows an altogether separate production route. The system boundary and inventory in this study is modeled on the feedstock (crude oil and natural gas) extracted in India. The calorific content of crude oil and natural gas is 9486 and $11443 \mathrm{kcal} / \mathrm{kg}$, respectively.

The main material used during extraction is cement (121 $\mathrm{mg}$ ), steel (11.18 g), chemicals (1.35 g) and lubricants (92.37 g) per $\mathrm{kg}$ of extracted crude oil. The extracted crude oil is sent to refineries where it undergoes several processes for conversion to multiple petroleum products including kerosene and LPG. The main fuel used for generating energy required for refinery processes is fuel oil $(25.48 \mathrm{~g} / \mathrm{kg}$ kerosene and $19.82 \mathrm{~g} / \mathrm{kg}$ LPG) and fuel gas $(40.98 \mathrm{~g} / \mathrm{kg}$ kerosene and $31.88 \mathrm{~g} / \mathrm{kg} \mathrm{LPG}$ ). The refinery losses are taken as $1.2 \%$. The calorific content of the produced kerosene and LPG is 10244 and $10812 \mathrm{kcal} / \mathrm{kg}$. The extracted natural gas is sent to the gas fractioning plants where it is processed into LPG and various other petrochemical products. The main energy carrier used in fractioning plant is steam $(56.26 \mathrm{~g})$ and natural gas $(62.80 \mathrm{~g})$ per $\mathrm{kg}$ of produced LPG. The fractioning losses are $4.2 \%$, which is considerably higher than those of refineries [47]. The LPG produced in refineries and fractioning plants are sent to the bottling plants where they are filled in steel cylinders ( $14.2 \mathrm{~kg}$ per cylinder), which are then supplied to households by distributor/retailer network spread over the entire country. The bottling plants mainly rely on grid electricity $(0.025 \mathrm{kWh} / \mathrm{kg}$ bottling of LPG) and the bottling losses are takes as 3.4\% [48]. Every 
stage of LPG and kerosene production chain involves storage, handling and transportation by various mediums (e.g. pipelines, sea tankers, locomotives, surface road tankers etc), which are accounted as physical losses at $0.5 \%$ for LPG and $1.5 \%$ for kerosene. The physical losses are higher lower for LPG as the bulk of the feedstock i.e. natural gas is supplied using pipelines and LPG is supplied in leak proof bottles. To account for distributor-retailer network, an average transportation distance of $250 \mathrm{~km}$ by road is considered in this study. As most of the kerosene stoves used in India are pressurized, a single burner 'pressurized' cook stove with $47 \%$ heat transfer efficiency [15] has been considered. LPG cooking devices use a pressure regulator which is connected to the cylinder by a rubber tube. For this study, a single burner LPG cook stove with $57 \%$ heat transfer efficiency [15] has been considered. The life cycle energy inventory of all five fossil fuels is presented in Table 5.

Table 5. Life cycle inventory (energy) of various cooking fuels

\begin{tabular}{|c|c|c|c|c|c|c|c|}
\hline $\begin{array}{l}\text { Cooking fuel/ } \\
\text { Life cycle stages }\end{array}$ & $\begin{array}{c}\text { Primary } \\
\text { Energy (Ep) }\end{array}$ & $\begin{array}{l}\text { Direct Energy } \\
\text { use }(E d)\end{array}$ & $\begin{array}{l}\text { Material use } \\
\quad(\mathrm{Em})\end{array}$ & $\begin{array}{l}\text { Fuel use } \\
\text { (Ef) }\end{array}$ & $\begin{array}{c}\text { Grid } \\
\text { electricity } \\
\text { use }(\mathrm{Ee})\end{array}$ & $\begin{array}{l}\text { Manual } \\
\text { Labour use } \\
\text { (Eh) }\end{array}$ & $\begin{array}{c}\text { Total } \\
\text { Energy } \\
\text { Input } \\
\text { (Et) }\end{array}$ \\
\hline & \multicolumn{7}{|c|}{ (in kcal per kg fuel or per kWh electricity) } \\
\hline \multicolumn{8}{|l|}{ LPG (Cr. Oil) } \\
\hline Extraction & \multirow{4}{*}{9486} & 1092 & 103 & 84 & 17 & $\mathrm{x}$ & 1296 \\
\hline Refinery & & 50 & 583 & 688 & 1 & $\mathrm{x}$ & 1322 \\
\hline Bottling & & $\mathrm{x}$ & $\mathrm{x}$ & $\mathrm{x}$ & 22 & $\mathrm{x}$ & 22 \\
\hline Transport & & $\mathrm{x}$ & $\mathrm{x}$ & 186 & $\mathrm{x}$ & $\mathrm{x}$ & 186 \\
\hline \multicolumn{8}{|l|}{ LPG (Nat. Gas) } \\
\hline Extraction & \multirow{2}{*}{11443} & 1104 & 103 & 84 & 16 & $\mathrm{x}$ & 1307 \\
\hline Fractioning & & 717 & 55 & $\mathrm{x}$ & 31 & $\mathrm{x}$ & 803 \\
\hline \multicolumn{8}{|l|}{ Kerosene } \\
\hline Refinery & \multirow{2}{*}{9486} & 60 & 1324 & 882 & 1 & $\mathrm{x}$ & 2267 \\
\hline Transport & & $\mathrm{x}$ & $\mathrm{x}$ & 81 & $\mathrm{x}$ & $\mathrm{x}$ & 81 \\
\hline \multicolumn{8}{|l|}{ Coal } \\
\hline Extraction & \multirow{2}{*}{2811} & $\mathrm{x}$ & 81 & 9 & $\mathrm{x}$ & $\mathrm{x}$ & 90 \\
\hline Transport & & $\mathrm{x}$ & $\mathrm{x}$ & 38 & $\mathrm{x}$ & $\mathrm{x}$ & 38 \\
\hline Electricity & 1802 & $\mathrm{x}$ & $\mathrm{x}$ & 23 & $\mathrm{x}$ & $\mathrm{x}$ & 23 \\
\hline Firewood & 3334 & $\mathrm{x}$ & $\mathrm{x}$ & $\mathrm{x}$ & $\mathrm{x}$ & 306 & 306 \\
\hline Crop residues & 3069 & $\mathrm{x}$ & $\mathrm{x}$ & $\mathrm{x}$ & $\mathrm{x}$ & 127 & 127 \\
\hline Dung cake & 1001 & $\mathrm{x}$ & $\mathrm{x}$ & $\mathrm{x}$ & $\mathrm{x}$ & 117 & 117 \\
\hline Charcoal & 3334 & $\mathrm{x}$ & $\mathrm{x}$ & $\mathrm{x}$ & $\mathrm{x}$ & 985 & 985 \\
\hline Biogas & 3705 & $\mathrm{x}$ & $\mathrm{x}$ & $\mathrm{x}$ & $\mathrm{x}$ & 332 & 332 \\
\hline
\end{tabular}

\section{Results and Discussions}

From the energy inventory Table 5, energy flow diagrams are prepared for analyzed cooking fuels and are presented in Fig. 1 and Fig. 2 for biomass and fossil cooking fuels, From Fig. 1 and 2 the impact of cook stove efficiency on the life cycle energy flow stream of various cooking fuels can be observed. The maximum loss of energy as waste heat takes place during the combustion process inside cook stove. The waste heat losses can be brought down to some extent by better stove design (high efficiency stoves), cooking methods (covering cook pots, pressure cookers, closed ovens etc) and periodic maintenance of cook stoves but there is a need to further intensify the research and development in cook stove design, particularly in biomass cook stoves. From Fig. 3 it can be seen that commercial fuels such as LPG and kerosene have much higher life cycle energy efficiency compared to biomass fuels except biogas. The main reasons are its higher calorific 
content and comparatively much better cook stove efficiency. The performance of coal is significantly lower because of its poor calorific value and stove efficiency. The performance of electricity for cooking activities is moderate despite much higher stove efficiency is primarily due to the huge transmission losses and poorer conversion efficiencies of coal power plants. The life cycle energy efficiency of biogas is almost comparable to those of LPG. Solid biomass fuels are characterized by poor energy to weight ratio which is evident from the energy flow diagram (refer Fig.1). Moreover, the traditional solid biofuels are typically combusted in mud stoves which have extremely poor heat transfer efficiency. The life cycle energy efficiency of charcoal is lower than those of firewood because of accumulated losses from pyrolysis process in the kiln during its production and the final combustion inside the cook stove. Although, some of the lost energy during pyrolysis is recovered as charcoals combustion efficiency is almost double of firewood but owing to 'law of energy conservation' the net energy loss will always remain slightly higher than direct combustion of firewood. However, the environmental (particularly indoor air pollution) and economic advantages associated with charcoal far outweighs the slight lowering in its energy efficiency. Dung cake has lowest energy efficiency amongst all the fuels analyzed. Comparing the energy efficiency performance of charcoal and biogas fuel systems, it can be said that fermentation processes are much more energy efficient than pyrolysis processes and are more suited for energy generation from biomass resources.

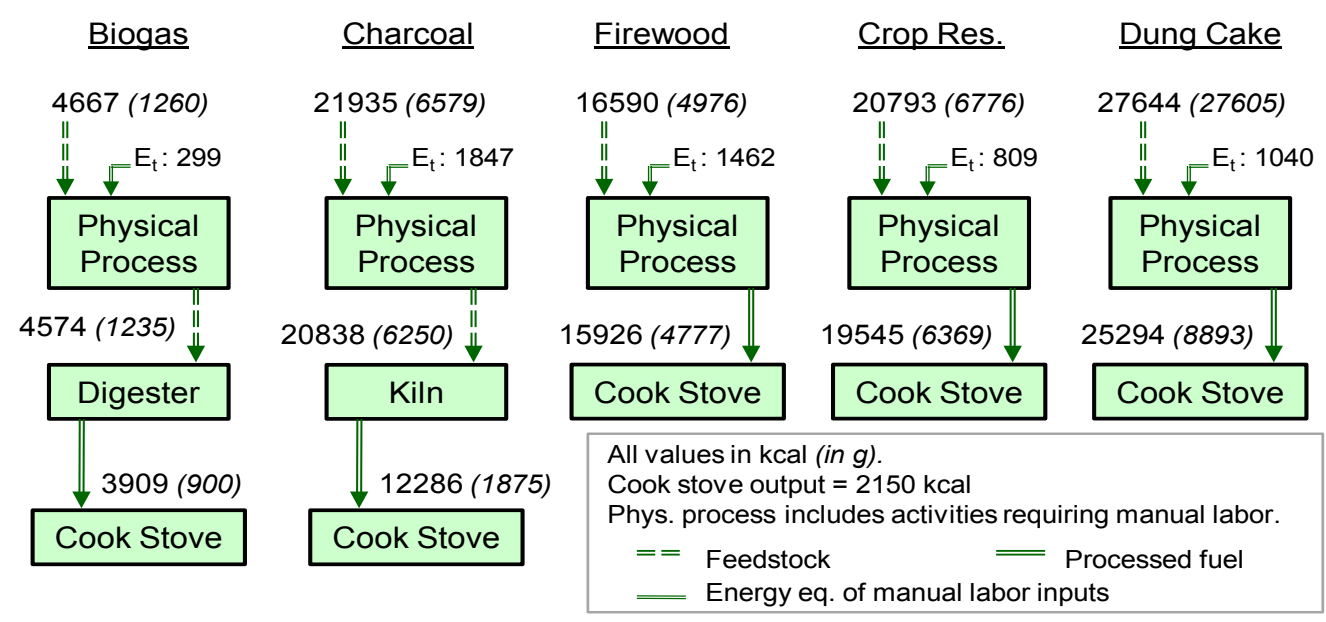

Figure 1. Energy flow diagram of biomass fuels used in household cooking

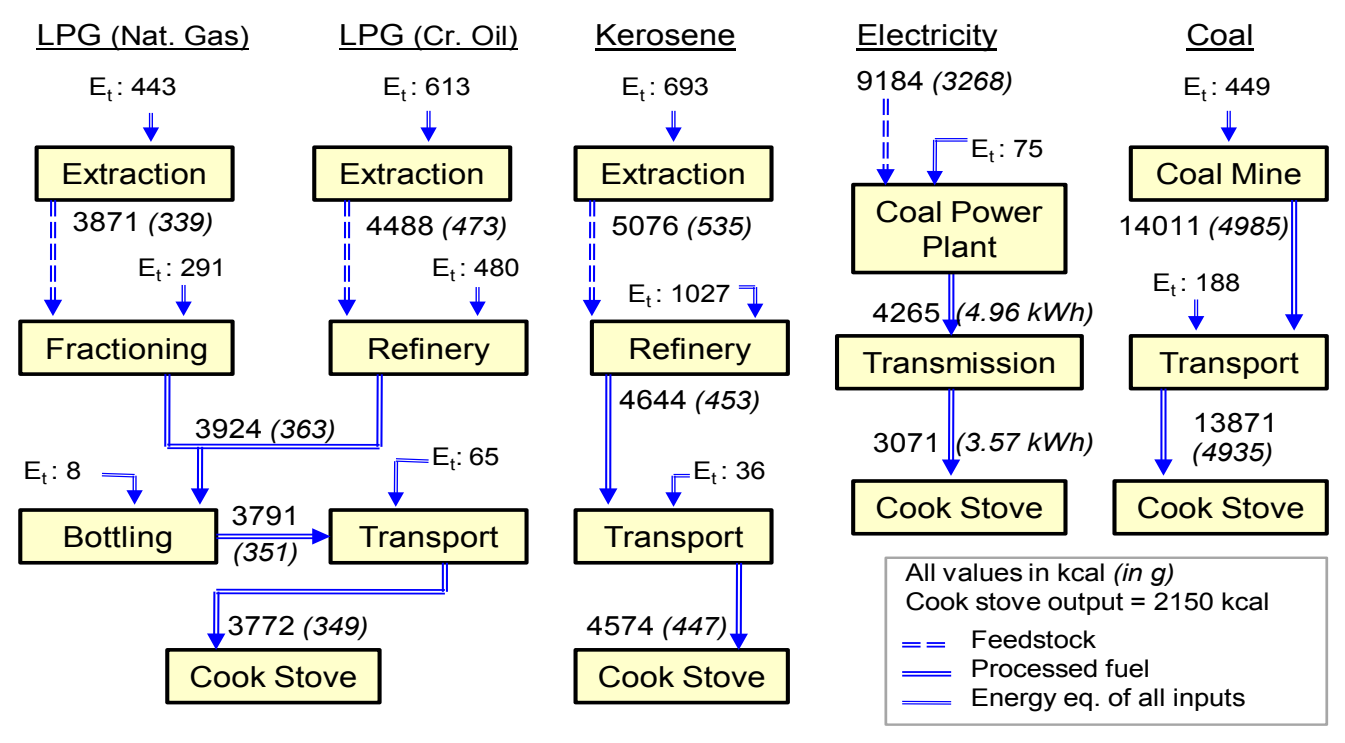

Figure 2. Energy flow diagram of fossil fuels used in household cooking 




Figure 3. Life cycle energy efficiency (LCEE) of various cooking fuels

\section{Conclusion}

The performance of commercial fossil fuels in terms of life cycle energy efficiency is significantly better than biomass fuels but they are essentially non renewable resources and hence cannot be a sustainable option. Moreover, considering their small share in meeting the present cooking energy requirements, particularly in rural areas, it is extremely unlikely that the accessibility and affordability of these commercial fuels to rural households are going to significantly improve in the near future. The steep increase in cost of crude oil and natural gas prices in the international markets will further raise the economic barriers impacting fuel transition towards commercial fuels, especially in rural and low income urban households. In view of the prevailing situation in India and other developing countries, it is important to shift the focus from fossil to biomass energy. Based on the results of this study, it can be said that biogas is a suitable cooking fuel option in terms of energy efficiency in Indian context because: (a) better life cycle energy efficiency of $43.3 \%$; (b) can be produced from completely renewable organic wastes; (c) high local availability of waste resources in the form of cattle dung, agricultural waste etc; and (d) India already has a vast experience of over three decades in biogas technology.

\section{Acknowledgements}

The authors express their gratitude to Mr. Mohite of M/s MKM Engineers, Thane for providing the precision instruments, cook stove modifications and workshop space needed for the experiments. The authors gratefully acknowledge the contribution of Mr. Sunil of M/S SimaPro (India) for providing LCA software and access to Ecoinvent database. We deeply appreciate the expert opinion and generous help given by Mr. Matthias Stucki (Zurich Univ. of Appl. Sciences, Switzerland), Dr. Niels Jungbluth (ESU-Services Ltd, Switzerland) and Dr. Ana Sesartic (C2SM, Switzerland) on various technical and other issues. We are thankful to Prof. K Narayanan, Prof. R Nagarajan,
Prof. S Pattanaik and Prof. B Rao for their valuable insights and wisdom on improving the study.

\section{REFERENCES}

[1] CensusIndia, Census of India Report, Ministry of Home Affairs, Government of India, 2011, Online available from www.censusindia.gov.in

[2] B. Sudhakara Reddy, Overcoming the energy efficiency gap in India's residential sector, Energy Policy, Vol. 31(11), 2003.

[3] N.H. Ravindranath \& J. Ramakrishna, J. (1997) Energy options for cooking in India, Energy Policy, 25, No. I. pp. 63-75, 1997.

[4] V. Laxmi, J. Parikh, S. Karmakar \& P. Dabrase, Household energy, women's hardship and health impacts in rural Rajasthan, India: need for sustainable energy solutions, Energy for Sustainable Development, 7(1), 2003.

[5] T.V. Ramachandra, G. Kamakshi \& B.V. Shruthi, Bioresource status in Karnataka, Renewable and Sustainable Energy Review, 8, pp. 1-47, 2004.

[6] B. Sudhakara Reddy, Economic and social dimensions of household energy use: A case study of India, In Ortega, E. \& Ulgiati, S. (ed): Proceedings of IV Biennial International Workshop “Advances in Energy Studies”, Brazil, pp. 469-77, 2004.

[7] J.B. Kandpal, R.C. Maheshwari \& T.C. Kandpal, Indoor air pollution from combustion of wood and dung cake and their processed fuels in domestic cookstoves, Energy Conversion and Management, 36(11), pp. 1073-79, 1995.

[8] L.P. Naeher, M. Brauer, M. Lipsett, J.T. Zelikoff et al., Woodsmoke health effects: A review, Inhalation Toxicology, 19, pp. 67-106, 2007.

[9] E. Duflo, M. Greenstone \& R. Hanna, Indoor air pollution, health and economic well-being. S.A.P.I.EN.S, 1(1), 2008, Online available from http://sapiens.revues.org/130.

[10] D. Behera \& G. Aggarwal, Domestic cooking fuel exposure and tuberculosis in Indian women, L.R.S. Institute of Tuberculosis and Respiratory Diseases, New Delhi, India, 
2009.

[11] D.G. Streets, T.C. Bond, G.R. Carmichael, S.D. Fernandes et al., An inventory of gaseous and primary aerosol emissions in Asia, Journal of Geophysical Research, Vol. 108, 2000.

[12] C. Venkataraman, G. Habib, A. Eiguren-Fernandez, A.H. Miguel \& S.K. Friedlander, Residential biofuels in South Asia: Carbonaceous aerosol emissions and climate impacts, Sicence, Vol. 307, 2005.

[13] V. Ramanathan \& Y. Feng, Air pollution, greenhouse gases and climate change: Global and regional perspectives, Atmospheric Environment, 43, pp. 37-50, 2009.

[14] T. Saud, R. Gautam, T.K. Mandal et al., Emission estimates of organic and elemental carbon from household biomass fuel used over the Indo-Gangetic Plain (IGP), India, Atmospheric Environment, 61, 2012.

[15] K.R. Smith, R. Uma, V.V.N. Kishore, J. Zhang, V. Joshi \& M.A.K. Khalil, Greenhouse implications of household stoves: An analysis for India, Annual Review of Energy and Environment, 25, 2000.

[16] M.S. Reddy \& C. Venkataraman, Inventory of aerosol and sulphur dioxide emissions from India: I-Fossil fuel combustion, Atmospheric Environment, 36, pp. 677-697, 2002.

[17] D. O'Rourke \& S. Connolly, Just oil? The distribution of environmental and social impacts of oil production and consumption, Annual Review of Environmental Resources, 28, pp. 587-617, 2003.

[18] H. Wake, Oil refineries: A review of their ecological impacts on the aquatic environment, Estuarine, Coastal and Shelf Science, 62, pp. 131-140, 2005.

[19] M.R. Narimisa \& N.E.A. Basri, A case study for environmental impact assessment of oil refinery in Iran with emphasis of environmental and social action plan (ESAP), $2^{\text {nd }}$ International Conference on Environmental Science and Technology IPCBEE, Vol. 6, IACSIT Press, Singapore, 2011.

[20] N. Lior, Energy resources and use the present situation and possible paths to the future, Energy, 33, pp. 842-857, 2008.

[21] G. Habib, C. Venkataraman, M. Shrivastava, R. Banerjee, J.W. Stehr \& R.R. Dickerson, New methodology for estimating biofuel consumption for cooking: Atmospheric emissions of black carbon and sulphur dioxide from India, Global Biogeochemical Cycles, Vol. 18, GB3007, 2004.

[22] M. Wang, H. Lee \& J. Molburg, Allocation of energy use in petroleum refineries to petroleum products, International Journal of Life Cycle Assessment, 9(1), pp. 34-44, 2004.

[23] R. Frischknecht, R. Heijungs \& P. Hofstetter, Einstein's lessons for energy accounting in LCA. International Journal of Life Cycle Assessment, 3(5), pp. 266-272. 1998.

[24] M. Rohrlich, M. Mistry, P.N. Martens, S. Buntenbach, et al., A method to calculate the cumulative energy demand (CED) of lignite extraction, International Journal of Life Cycle Assessment, 5(6), pp. 369-73, 2000.

[25] M. Patel, Cumulative energy demand (CED) and cumulative $\mathrm{CO} 2$ emissions for products of the organic chemical industry, Energy, 28, pp. 721-740, 2003.
[26] J. Malca \& F. Freire, Renewability and life-cycle energy efficiency of bioethanol and bio-ethyl tertiary butyl ether (bioETBE): Assessing the implications of allocation, Energy, 31, pp. 3362-80, 2006.

[27] S. Papong \& P. Malakul, Life cycle energy and environmental analysis of bioethanol production from cassava in Thailand, Bioresource Technology, 101, pp. S112-S118, 2010.

[28] C. Venkataraman, A.D. Sagar, G. Habib, N. Lam \& K.R. Smith, The Indian national initiative for advanced biomass cookstoves: The benefits of clean combustion. Energy for Sustainable Development, 14, 2010.

[29] NSSO, Household consumption of various goods and services, National Sample Survey $66^{\text {th }}$ Round (July 2009-June 2010), MOSPI, Government of India, Online available from http://mospi.nic.in, 2012.

[30] P.S. Anoopa, S. Dayana,, Nithya et al., Energy consumption benchmark studies on parboiled rice cooking in Kerala, Energy Management Centre, Kerala, Online available from www.keralaenergy.gov.in on, 2007.

[31] T.W. Zhang \& D.A. Dornfeld, Energy use per worker-hour: Evaluating the contribution of labor to manufacturing energy use, $14^{\text {th }}$ CIRP International conference on life cycle engineering (June 11-13), Tokyo, Japan, Online available from http://www.escholarship.org, 2007.

[32] IEA, Energy balance for India, International Energy Agency, Online available from www.iea.org on $19^{\text {th }} \mathrm{Jan}, 2013,2009$.

[33] MoF, Economic survey of India 2012-13, Min. of Finance, Govt. of India, Online available from http://indiabudget.nic.in, 2013.

[34] M.A.J. Huijbregts, L.J.A Rombouts, S. Hellweg, et al., Is cumulative fossil energy demand a useful indicator for the environmental performance of the product?, Environment, Science and Technology, 40(3), 2006.

[35] R. Frischknecht, N. Jungbluth, H.J. Althaus, et al., Overview and Methodology, Ecoinvent report No. 1, Swiss Centre for Life Cycle Inventories, Dübendorf, Switzerland, 2007.

[36] R. Frischknecht, H.J. Althaus, R. Dones, et al., Renewable energy assessment within the cumulative energy demand concepts: Challenges and solutions, Ecoinvent Centre, Switzerland, Unpublished

[37] H. Pathak, A. Bhatia \& N. Jain, Inventory of greenhouse gas emission from agriculture, Report submitted to MNRE, Govt. of India, Online available from http://www.mnre.gov.in/, 2010 .

[38] A.K. Dikshit \& P.S. Birthal, Environmental value of dung in mixed crop-livestock systems, Indian Journal of Animal Sciences, 80 (7), pp. 679-82, 2010.

[39] M. Harsdorff, The economics of cow dung: A green value chain analysis of the cow dung and dairy industry in Jabalpur, MP, Green Jobs Program, International Labour Organisation, 2012.

[40] K.R. Smith, D.M. Pennise, et al., Greenhouse gases from small-scale combustion devices in developing countries: Charcoal-making kilns in Thailand, Environmental Protection Agency EPA-600/R-99-109, Washington DC, 1999.

[41] N. MacCarty, D. Ogle, D. Still, T. Bond \& C. Roden, A 
laboratory comparison of the global warming impact of five major types of biomass cooking stoves, Energy for Sustainable Development, 12(2), 2008.

[42] Bagepalli CDM Project, Project definition document, CDM Project No. 0121, Online available from http://www.cdm.unfecc.int, 2007.

[43] M.K. Ghose, Emission factors for the quantification of dust in Indian coal mines, Journal of Scientific and Industrial Research, 63, 2004.

[44] M.K. Ghose, Generation and quantification of hazardous dusts from coal mining in the Indian context, Environmental Monitoring and Assessment, doi: 10.1007/s10661-006-9451, 2007.
[45] S. Roy, G.R. Adhikari and T.N. Singh, Development of emission factors for quantification of blasting dust at surface Coal mines, Journal of Environmental Protection, 1, doi:10.4236/jep.2010.14041, 2010.

[46] CEA, Operation Performance of Generating Stations in the Country during 2009-10, Central Electricity Authority, Govt. of India, Online available from http://www.cea.nic.in, 2010.

[47] ONGC, Annual Report 2010-11, Oil and Natural Gas Corporation Ltd., Online available from www.ongcindia.com, 2011.

[48] IOCL, Annual Report 2010-11, Indian Oil Corporation Limited, Online available from www.iocl.com, 2011. 